\title{
Milk as a food for growth? The insulin-like growth factors link
}

\author{
Imogen Rogers ${ }^{1, *}$, Pauline Emmett ${ }^{1}$, David Gunnell ${ }^{2}$, David Dunger ${ }^{3}$, Jeff Holly ${ }^{4}$ and the \\ ALSPAC Study Team \\ 'Unit of Paediatric and Perinatal Epidemiology, Division of Community Medicine, University of Bristol, 24 Tyndall \\ Avenue, Bristol BS8 1TQ, UK: ${ }^{2}$ Department of Social Medicine, University of Bristol, Canynge Hall, Whiteladies \\ Road, Bristol BS8 2PR, UK: ${ }^{3}$ Department of Paediatrics, University of Cambridge, Addenbrookes Hospital, Level 8, \\ Box 1 16, Cambridge CB2 2QQ, UK: ${ }^{4}$ Division of Surgery, University of Bristol, Bristol BS8 2HW, UK
}

Submitted 21 December 2004: Accepted 18 July 2005

\begin{abstract}
Objective: The mechanisms underlying the association of insulin-like growth factor-I (IGF-I) and leg length (a marker of prepubertal growth) with cancer risk are uncertain. One hypothesis is that diet in early childhood might provide the link. The aim of the present study was to examine the association between early diet - in particular, the intakes of cows' milk and dairy products - and height, leg length and IGF-I levels at age $7-8$ years.

Subjects: Children participating in the Avon Longitudinal Study of Parents and Children.

Design: Diet was assessed using a 3-day unweighed food record. Anthropometry, IGF-I and insulin-like growth factor-binding protein-3 (IGFBP-3) were measured by standard methods.

Results: Data on both diet and height were available for 744 children ( 404 boys) and on diet and IGF for 538 (295 boys). After adjusting for energy, both cows' milk and dairy product intakes were positively associated with IGF-I $(P=0.040$ and 0.027 , respectively) and IGFBP-3 levels $(P=0.082$ and 0.067 , respectively). These associations persisted on adjustment for potential confounders, but were abolished on controlling for protein intake. In energy-adjusted models there was only weak evidence of associations of milk and dairy product intakes with anthropometry. In boys only, dairy product intake was positively associated with leg length (equivalent to a $0.058(0.002,0.114)$ standard deviation score increase in leg length per $100 \mathrm{~g}$ increase in daily intake).

Conclusions: These data provide some evidence that variation in childhood milk and dairy product intakes underlies associations of leg length, IGF-I and cancer risk. The association appears to be due to the protein content of milk.
\end{abstract}

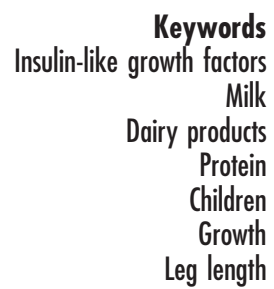

Greater adult stature is associated with cancer risk, in particular with prostate, breast and gastrointestinal cancers $^{1}$. Some evidence suggests that leg length, a marker for growth before puberty ${ }^{2}$, is the component of height most strongly associated with risk ${ }^{1,3}$. Growth in leg length is thought to be more sensitive to environmental insults than truncal growth, and adult leg length has been suggested to be a marker of prepubertal influences on growth such as childhood $\operatorname{diet}^{4}$. This suggests that the biological mechanisms linking height with cancer risk may originate in factors that influence long bone growth in childhood. It is possible that these associations between prepubertal growth and cancer risk operate via dietary effects on levels of insulin-like growth factors (IGFs), as IGFs are key hormonal regulators of growth ${ }^{5,6}$.

The IGFs are powerful mitogenic agents which stimulate cell differentiation and inhibit apoptosis. Higher circulating levels of insulin-like growth factor-I (IGF-I) are associated with increased risk of a number of cancers, including prostate ${ }^{7,8}$, breast ${ }^{9}$ and colon cancer ${ }^{10}$, the same cancers most consistently associated with height. Some studies have found inverse associations between concentrations of insulin-like growth factor-binding protein-3 (IGFBP-3) and cancer risk ${ }^{11,12}$, but a recent meta-analysis has suggested a positive association ${ }^{13}$. The risk of these cancers has also been associated with dietary factors, including positive associations with intakes of energy, red meat, animal fat, calcium and dairy products ${ }^{14-18}$, and negative associations with fruit and vegetables ${ }^{18-22}$. Several cross-sectional studies in adults have investigated the relationship between diet and IGF-I levels. The results are mixed, but one of the more consistent relationships is a positive association between cows' milk or dairy product intake and IGF-I ${ }^{10,23-25}$, although this is not observed in all studies $^{26-28}$. Milk supplementation has also been observed to raise IGF-I levels in three studies, one of 
middle-aged men and women ${ }^{29}$, one of adolescent girls ${ }^{30}$ and one in 8 -year-old boys ${ }^{31}$. However, it remains unclear what constituent of cows' milk/dairy products is responsible for their positive effect on circulating IGF-I.

Evidence that childhood diet may affect adult cancer risk is provided by a long-term follow-up of the Boyd Orr cohort, which found that childhood energy intakes were positively associated with cancer mortality in adulthood ${ }^{32}$. The associations of dietary intakes in prepubertal children with IGF levels and growth have been less often studied but are of considerable interest. Such associations could confirm that leg length measures are a marker of childhood nutrition and that IGF-I is the biological mediator of the associations of diet and anthropometry with cancer risk in later life. The associations of cows' milk and dairy products with IGF-I are of particular interest in this context, as children are high consumers of these foods, often marketed as 'healthy' foods for this age group. However, we are aware of only one study that has investigated the associations of milk and dairy product intakes with both IGF-I and measures of linear growth in children $^{33}$.

The aim of the present study was to investigate associations of cows' milk and dairy product intakes with levels of IGF-I and IGFBP-3 in a group of 7- and 8year-old children in the South West of England. In addition we examined the associations between these foods and height and leg length - possible biomarkers of IGF-I ${ }^{4,6}$.

\section{Methods}

This study was based on the Avon Longitudinal Study of Parents and Children (ALSPAC), a geographically based cohort study investigating factors influencing the health, growth and development of children ${ }^{34}$. All pregnant women resident within a defined part of the former county of Avon in South West England with an expected date of delivery between April 1991 and December 1992 were eligible. Between $80 \%$ and $90 \%$ of these enrolled (14541 pregnancies resulting in 14062 live births) ${ }^{35}$. Ethical approval for the study was obtained from the relevant local ethics committees. Data in ALSPAC are collected by self-completion postal questionnaires, abstracted from medical records, and from examination of the children at research clinics.

The children forming the basis of the present analysis were part of a randomly selected 10\% sub-cohort of ALSPAC called Children in Focus (CIF) $(n=1432)^{35}$. The children attended research clinics at $7-8$ years of age where diet was assessed, growth measurements were made and a blood sample was taken.

\section{Assessment of diet}

Diet was assessed using a 3-day unweighed dietary record completed by the child's carer in advance of the clinic, and checked for completeness by a trained assistant during the clinic visits. These were coded using the coding package DIDO $^{36}$, and analysed using a database consisting of the 5th edition of McCance \& Widdowson's The Composition of Foods ${ }^{37}$ and its supplements ${ }^{38-46}$. Nutrient intakes from dietary supplements were not assessed; $9.3 \%$ of children were reported to take a vitamin or mineral supplement of some kind, and $0.7 \%$ of children took cod-liver oil.

\section{Measurement of antbropometric variables}

Height, leg length and sitting height were measured to the last completed millimetre using a Harpenden stadiometer, a sitting height table and an anthropometer as described by Cameron ${ }^{47}$. Weight was measured to the nearest $50 \mathrm{~g}$ using a Tanita weighing scale (Tanita UK Limited, Uxbridge). Body mass index (BMI) was calculated as weight $(\mathrm{kg}) /[\text { height }(\mathrm{m})]^{2}$.

\section{Measurement of other variables}

Information on maternal education, housing tenure, paternal social class and maternal smoking in pregnancy was obtained from a self-completion questionnaire sent to the mother at 32 weeks' gestation. Birth weight, sex of the child and gestation were obtained from hospital records. Gestational age was assessed on the basis of date of last menstrual period, ultrasound assessment and other clinical indicators.

\section{Assessment of IGF levels}

Serum levels of IGF-I were determined in venous blood by radioimmunoassay using a monoclonal antibody (Blood Products, Elstree, Hertfordshire, UK) and recombinant peptide (Pharmacia, Stockholm, Sweden) for standard and tracer, following iodination using the chloramine-T method. Samples were analysed following acid-acetone extraction to remove the IGFBPs with an excess of IGF-II added to the extract in order to saturate any residual binding proteins ${ }^{48}$. Serum levels of IGFBP-3 were determined by radioimmunoassay using an in-house polyclonal antibody raised against recombinant nonglycosylated IGFBP-3. The assay was calibrated against recombinant glycosylated IGFBP-3 (Dr C Maack, Celitrix, Santa Clara, CA, USA). The molar ratio of IGF-I/IGFBP-3 was calculated by multiplying the concentration ratio by 5.33 (based on the molecular weights of IGF-I (7500) and IGFBP-3 (40 000)). The average coefficients of variation for intra-assay variability for IGF-I and IGFBP-3 were 6.7\% and $3.6 \%$, and for inter-assay variation were $12 \%$ and $14 \%$.

\section{Statistical methods}

All hormone levels and anthropometric variables were adjusted for age. IGF-I, IGFBP-3 and IGF-I/IGFBP-3 were transformed to the natural logarithm prior to age adjustment in order to reduce skewness. Age-adjusted anthropometric variables were converted to sex-specific $Z$-scores ( $Z$-scores were produced with reference to the ALSPAC cohort). 
Intakes of cows' milk and dairy products were the main predictor variables of interest. Cows' milk was defined as the sum of whole, semi-skimmed and skimmed milk. Dairy products were defined as the sum of cows' milk, other milk (i.e. dried milk, evaporated milk and cream), cheese, yoghurt, milk-based sauces, ice cream and milk chocolate. Intakes of calcium, protein and animal protein were also considered as possible mediators of the effects of cows' milk and dairy products. Intakes of calcium, protein and animal protein were adjusted for energy using the residuals method ${ }^{49}$.

The following confounding variables were considered: maternal education, housing tenure, birth weight and the child's BMI. Highest maternal educational level was grouped as CSE (Certificate of Secondary Education) or equivalent or no qualifications, vocational qualifications, O-level or equivalent, A-level or equivalent, or university degree (CSE and O-levels are respectively lower and higher levels of qualifications taken at around 16 years of age, A-levels are the standard qualifications taken at around 18 years of age). Housing tenure was grouped as council rented (i.e. government housing), other rented, and owned/mortgaged. Birth weight was adjusted for gestational age and converted to sex-specific $Z$-scores. Paternal social class and maternal smoking in pregnancy were also initially considered as potential confounders, but found to be minimally associated with IGF or growth once the other confounders had been considered.

Only white children not from multiple births were included in analyses, as preliminary analyses suggested that the growth and IGF levels of children from non-white ethnic groups differed from those of white children, and there were too few children from non-white ethnic groups to analyse separately. After excluding subjects who were non-white or from multiple births, there were 744 subjects with both diet and height measures (i.e. $59 \%$ of the white singleton children in the CIF sub-cohort) and 538 with both diet and IGF. Multivariate models are based on a smaller subset of subjects ( $n=521$ children, 287 boys) with complete information on all confounders.

Linear (least squares) regression models were used. Initial statistical analyses were performed firstly for both sexes together and then separately for boys and girls, as previous studies have shown that IGF-I and IGFBP-3 levels differ between boys and girls ${ }^{6,50}$, and the relationship between IGF-I and IGFBP-3 and age is also different between boys and girls ${ }^{50}$. In the first instance the association between cows' milk and dairy products and the outcome variables was assessed controlling for energy only. Subsequent multivariable regression analyses included other confounders and were based on a subgroup of children where complete data were available; the confounding variables included in the statistical models were as follows: (1) energy intake (Model 1); (2) energy intake, housing tenure, maternal education, birth weight and BMI (Model 2); (3) factors included in Model 2 plus IGF-I for models looking at height, leg length and sitting height, or height in models looking at IGF-I, IGFBP3 and IGF-I/IGFBP-3 (Model 3); (4) in Models 4-6 we examined the effect of adjusting additionally for those nutrient variables that we felt might mediate any associations with cows' milk and dairy products, i.e. calcium, protein and animal protein.

In order to assess the possible effects of underreporting of dietary intake, all analyses were repeated excluding those children reporting an energy intake of less than $1.39 \times$ estimated basal metabolic rate (BMR) for boys or $1.30 \times$ BMR for girls ${ }^{51}$.

All analyses were performed using SPSS version 10 (SPSS Inc., Chicago, IL, USA).

\section{Results}

\section{Response rate and representativeness of sample}

Some characteristics of study members are displayed in Table 1. IGF-I and IGFBP-3 were higher in girls than boys, but IGF-I/IGFBP-3 was similar in the two sexes. The children were slightly taller and heavier than national growth standards ${ }^{52}$

Girls (but not boys) for whom data on IGF levels were available were significantly taller with longer legs than those for whom data on IGF levels were not available (mean height and leg length in those with and without IGF measures were $125.5 \mathrm{~cm}$ and $124.1 \mathrm{~cm}, P=0.019$ and $57.8 \mathrm{~cm}$ and $57.0 \mathrm{~cm}, P=0.031$ respectively). Children with data on IGF were less likely to live in council housing

Table 1 Mean (SD) IGF-I and IGFBP-3 levels, growth measures and dietary intakes in boys and girls

\begin{tabular}{|c|c|c|}
\hline & Boys & Girls \\
\hline & $n=404^{*}$ & $n=340^{*}$ \\
\hline Mean age (years) & $7.48(0.12)$ & $7.49(0.11)$ \\
\hline Height $(\mathrm{cm}) \dagger$ & $125.9(5.0)$ & $125.2(5.4)$ \\
\hline Weight $(\mathrm{kg}) \ddagger$ & $25.7(4.4)$ & $25.7(4.8)$ \\
\hline Sitting height $(\mathrm{cm})$ & $68.1(2.7)$ & $67.6(2.7)$ \\
\hline Leg length $(\mathrm{cm})$ & $57.8(3.0)$ & $57.6(3.4)$ \\
\hline BMl $\left(\mathrm{kgm}^{-2}\right)$ & $16.1(1.9)$ & $16.3(2.3)$ \\
\hline Cows' milk intake (g) & 278 (195) & $243(187)$ \\
\hline Dairy products intake (g) & 348 (209) & 313 (193) \\
\hline Energy intake (kJ) & 7295 (1339) & 6858 (1211) \\
\hline Calcium intake (mg) & $810(280)$ & $757(256)$ \\
\hline Protein intake $(\mathrm{g})$ & $56.7(12.8)$ & $52.8(11.5)$ \\
\hline Animal protein intake (g) & $33.8(11.4)$ & $31.4(10.4)$ \\
\hline & $\begin{array}{l}n=295 \S \\
145(55)\end{array}$ & $\begin{array}{l}n=243 \S \\
154(52)\end{array}$ \\
\hline IGFBP-3 (ng ml $\left.{ }^{-1}\right)$ & $\begin{array}{l}145(55) \\
4883(1669)\end{array}$ & $\begin{array}{l}154(52) \\
5122(1943)\end{array}$ \\
\hline IGF-I/IGFBP-3 & $0.167(0.063)$ & $0.172(0.058)$ \\
\hline
\end{tabular}

SD - standard deviation; IGF-I - insulin-like growth factor-I; IGFBP-3 insulin-like growth factor-binding protein-3; BMI - body mass index.

* The sample used is those boys and girls with both a diet and a height measure.

† Median height from UK reference data: $124.9 \mathrm{~cm}$ (boys) $124.3 \mathrm{~cm}$ (girls) $^{52}$.

$\ddagger$ Median weight from UK reference data: $24.3 \mathrm{~kg}$ (boys) $/ 24.4 \mathrm{~kg}$ (girls) ${ }^{52}$. $\S$ The sample used is those boys and girls with both IGF and a diet measure. 
(8.4\% vs. $14.3 \%, P<0.001$ ) and less likely to have a mother whose highest educational qualification was CSE or less $(10.4 \%$ vs. $18.7 \%, P<0.001)$.

\section{Univariable analyses}

Table 2 shows geometric mean levels of IGF-I, IGFBP-3 and IGF-I/IGFBP-3 by quartile of cows' milk and dairy products intakes. Among both sexes after adjusting for energy intake, cows' milk and dairy products were positively associated with IGF-I $(P=0.040$ and 0.027 , respectively) and weakly positively associated with IGFBP-3 ( $P=0.082$ and 0.067 , respectively). Among boys, after adjustment for energy intake, cows' milk was weakly positively associated with IGF-I $(P=0.084)$ and significantly positively associated with IGFBP-3 $(P=0.024)$. Dairy products were also positively associated with IGF-I and IGFBP-3, with a difference in IGF-I concentrations of approximately $20 \mathrm{ng} \mathrm{ml}^{-1}$ between the lowest and highest quartiles of dairy products intake. Among girls, neither cows' milk nor dairy products intake was associated with either IGF-I or IGFBP-3. These gender-specific subgroup findings should be interpreted with caution, as there was little statistical evidence that effects of diet on IGF differed in boys and girls. The $P$ values for the interaction terms gender $\times$ cows' milk and gender $\times$ dairy products on IGF-I were 0.37 and 0.16 , respectively, and for IGFBP-3 were 0.13 and 0.16 , respectively. IGF-I/IGFBP-3 was not associated with cows' milk or dairy products in either the whole sample or boys and girls separately (data not shown).

Table 3 shows mean $Z$-scores for height, leg length and sitting height according to intakes of cows' milk and dairy products. On adjusting for energy intake there were no clear associations between intake of either food group and anthropometry, except for a weak positive association between dairy products and leg length in boys $(P=0.069)$. There was some evidence that diet-anthropometry associations differed in boys and girls. The $P$ values for the interaction terms cows' milk $\times$ gender and dairy products $\times$ gender with respect to height were 0.040 and 0.043 , respectively, and for leg length were 0.013 and 0.015 , respectively.

\section{Multivariable analyses}

Table 4 shows the associations of cows' milk and dairy products with IGF-I and IGFBP-3 in multivariable analyses in all children. The univariable positive associations between cows' milk and dairy products and IGF-I remained significant in the subset with complete data. Of the possible confounding/mediating factors investigated, only protein/

Table 2 Geometric mean (95\% Cl) IGF-I and IGFBP-3 levels according to quartile of cows' milk or dairy products intake (quartiles calculated separately in boys and girls)

\begin{tabular}{|c|c|c|c|c|c|c|}
\hline & \multicolumn{4}{|c|}{ Quartile of intake } & \multirow[b]{2}{*}{$P^{*}$} & \multirow[b]{2}{*}{$P \dagger$} \\
\hline & 1 (low) & 2 & 3 & 4 (high) & & \\
\hline \multicolumn{7}{|l|}{ Both sexes } \\
\hline Cows' milk & $(n=143)$ & $(n=135)$ & $(n=136)$ & $(n=124)$ & & \\
\hline Median intake (g) & 67 & 187 & 301 & 462 & & \\
\hline IGF-I (ng ml $\left.\left.\right|^{-1}\right)$ & $133.6(125.4,142.4)$ & $139.0(130.5,148.2)$ & $141.0(133.1,149.3)$ & $141.8(134.1,150.0)$ & 0.017 & 0.040 \\
\hline IGFBP-3 (ng ml $\left.{ }^{-1}\right)$ & $4467(4262,4681)$ & $4661(4434,4899)$ & $4709(4477,4953)$ & $4749(4503,5009)$ & 0.011 & 0.082 \\
\hline Dairy products & $(n=131)$ & $(n=141)$ & $(n=133)$ & $(n=133)$ & & \\
\hline Median intake (g) & 113 & 257 & 401 & 631 & & \\
\hline IGF-I (ng ml $\left.\left.\right|^{-1}\right)$ & $133.8(125.3,143.0)$ & $138.8(130.3,147.9)$ & $138.0(130.3,146.1)$ & $144.3(136.6,152.4)$ & 0.010 & 0.027 \\
\hline IGFBP-3 (ng ml $\left.{ }^{-1}\right)$ & $4451(4230,4683)$ & $4599(4389,4819)$ & $4688(4457,4931)$ & $4831(4588,5088)$ & 0.005 & 0.067 \\
\hline \multicolumn{7}{|l|}{ Boys } \\
\hline Cows' milk & $(n=76)$ & $(n=72)$ & $(n=75)$ & $(n=72)$ & & \\
\hline Median intake (g) & 67 & 200 & 314 & 503 & & \\
\hline IGF-I $\left(\mathrm{ng} \mathrm{ml}^{-1}\right)^{\text {lol }}$ & $123.7(112.4,136.1)$ & $137.2(126.5,148.8)$ & $136.8(125.8,148.7)$ & $139.5(128.8,151.1)$ & 0.023 & 0.084 \\
\hline IGFBP-3 (ng ml $\left.{ }^{-1}\right)$ & $4359(4080,4656)$ & $4474(4216,4748)$ & $4635(4322,4970)$ & $4809(4486,5155)$ & 0.003 & 0.024 \\
\hline Dairy products & $(n=70)$ & $(n=76)$ & $(n=74)$ & $(n=75)$ & & \\
\hline Median intake $(\mathrm{g})$ & 123 & 260 & 397 & 588 & & \\
\hline IGF-I (ng m| $\left.\left.\right|^{-1}\right)$ & $125.3(113.7,138.1)$ & $132.5(121.7,144.3)$ & $132.9(122.6,144.0)$ & $145.5(134.5,157.5)$ & 0.006 & 0.031 \\
\hline IGFBP-3 (ng ml $\left.{ }^{-1}\right)$ & $4383(4073,4716)$ & $4410(4180,4652)$ & $4540(4229,4873)$ & $4933(4617,5272)$ & 0.002 & 0.022 \\
\hline \multicolumn{7}{|l|}{ Girls } \\
\hline Cows' milk & $(n=67)$ & $(n=63)$ & $(n=61)$ & $(n=52)$ & & \\
\hline Median intake (g) & 65 & 167 & 293 & 442 & & \\
\hline IGF-I (ng ml $\left.{ }^{-1}\right)$ & $145.9(135.0,157.8)$ & $141.2(127.4,156.4)$ & $146.3(135.3,158.2)$ & $145.1(134.1,157.0)$ & 0.34 & 0.29 \\
\hline IGFBP-3 (ng ml $\left.\left.\right|^{-1}\right)$ & $4592(4293,4911)$ & $4883(4496,5304)$ & $4801(4456,5174)$ & $4668(4288,5081)$ & 0.61 & 0.90 \\
\hline Dairy products & $(n=61)$ & $(n=65)$ & $(n=59)$ & $(n=58)$ & & \\
\hline Median intake (g) & 109 & 228 & 358 & 499 & & \\
\hline IGF-I $\left(\mathrm{ng} \mathrm{ml}^{-1}\right)$ & $144.3(132.3,157.3)$ & $146.6(133.2,161.4)$ & $144.6(133.4,156.8)$ & $142.7(132.3,154.0)$ & 0.53 & 0.44 \\
\hline IGFBP-3 (ng ml $\left.\left.\right|^{-1}\right)$ & $4530(4218,4865)$ & $4830(4460,5241)$ & $4880(4540,5245)$ & $4703(4326,5112)$ & 0.49 & 0.84 \\
\hline
\end{tabular}

Cl-confidence interval; IGF-I - insulin-like growth factor-I; IGFBP-3 - insulin-like growth factor-binding protein-3.

${ }^{*} P$-value for continuous variable.

$\dagger P$-value for continuous variable adjusted for energy intake. 


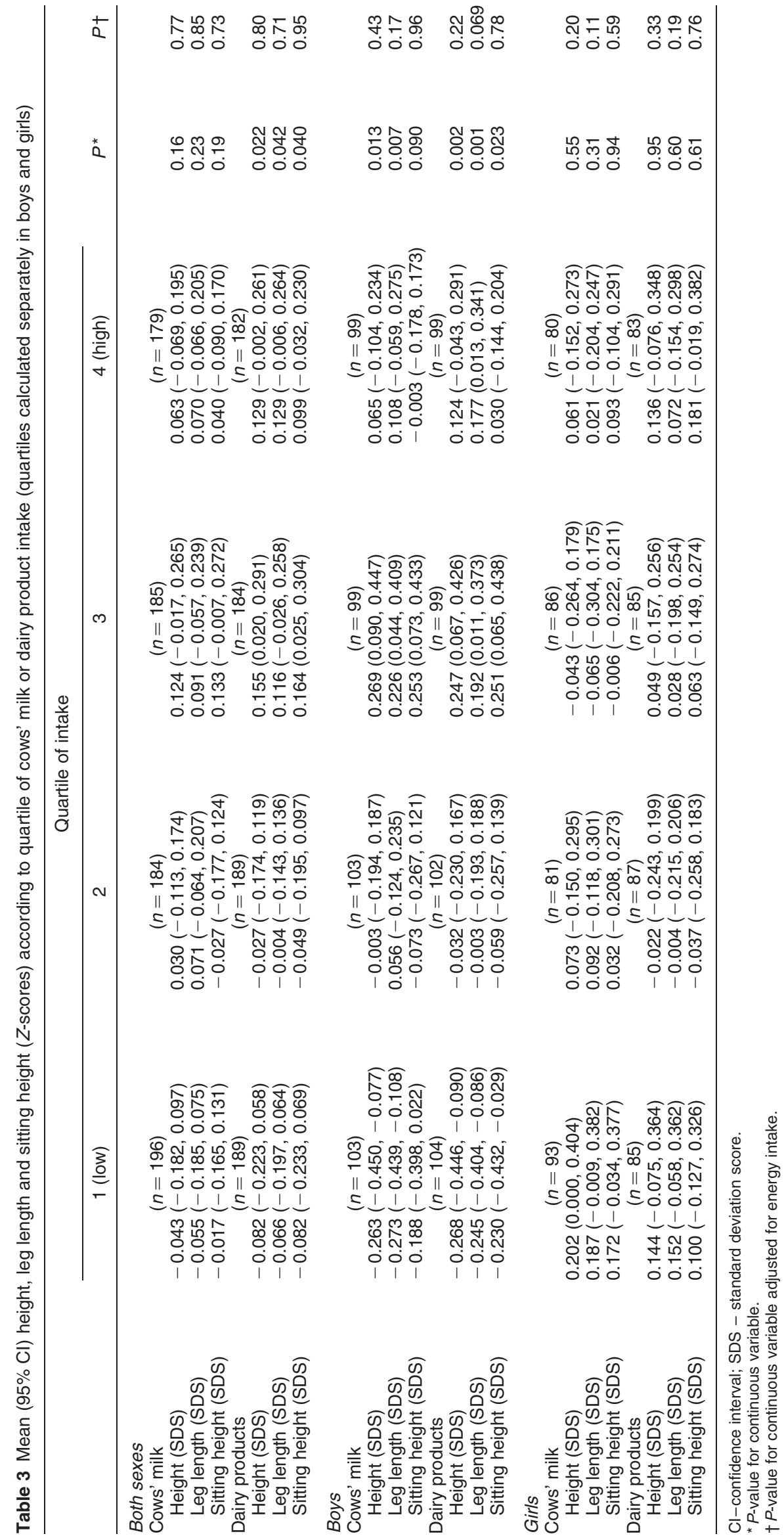


Table 4 Percentage change in IGF-I and IGFBP-3 per $100 \mathrm{~g}$ increase in cows' milk or dairy products consumption among both sexes $(n=521)$

\begin{tabular}{|c|c|c|c|c|}
\hline \multirow[b]{2}{*}{ Outcome variable } & \multicolumn{2}{|c|}{ Cows' milk } & \multicolumn{2}{|c|}{ Dairy products } \\
\hline & $B(95 \% \mathrm{Cl})$ & $P$ & $B(95 \% \mathrm{Cl})$ & $P$ \\
\hline \multicolumn{5}{|l|}{ IGF-I } \\
\hline Model 1 & $2.12(0.40,3.87)$ & 0.014 & $2.12(0.50,3.87)$ & 0.011 \\
\hline Model 2 & $2.33(0.60,3.98)$ & 0.007 & $2.12(0.50,3.77)$ & 0.011 \\
\hline Model 3 & $2.33(0.70,3.98)$ & 0.004 & $2.02(0.50,3.67)$ & 0.009 \\
\hline Model 4 & $2.02(-0.80,4.92)$ & 0.17 & $1.41(-1.88,4.71)$ & 0.42 \\
\hline Model 5 & $0.90(-0.80,2.74)$ & 0.29 & $0.60(-1.09,2.33)$ & 0.47 \\
\hline Model 6 & $1.11(-0.70,2.94)$ & 0.24 & $0.70(-1.09,2.53)$ & 0.46 \\
\hline \multicolumn{5}{|l|}{ IGFBP-3 } \\
\hline Model 1 & $1.41(0.00,3.23)$ & 0.046 & $1.41(0.00,2.74)$ & 0.046 \\
\hline Model 2 & $1.51(0.10,2.94)$ & 0.036 & $1.31(-0.10,2.63)$ & 0.061 \\
\hline Model 3 & $1.51(0.10,2.94)$ & 0.032 & $1.31(-0.10,2.63)$ & 0.061 \\
\hline Model 4 & $2.63(0.10,5.13)$ & 0.039 & $2.53(-0.30,5.55)$ & 0.077 \\
\hline Model 5 & $1.41(-0.09,2.94)$ & 0.074 & $1.11(-0.40,2.63)$ & 0.14 \\
\hline Model 6 & $1.82(0.20,3.36)$ & 0.029 & $1.51(-0.10,3.15)$ & 0.058 \\
\hline
\end{tabular}

$\mathrm{CI}$ - confidence interval; IGF-I - insulin-like growth factor-I; IGFBP-3 - insulin-like growth factor-binding protein-3.

Model 1 - adjusted for sex and energy intake; Model 2 - adjusted for sex, energy intake, housing tenure, maternal education, birth weight and body mass index (BMI); Model 3 - adjusted for sex, energy intake, housing tenure, maternal education, birth weight, BMI and height; Model 4 - adjusted for sex, energy intake, housing tenure, maternal education, birth weight, BMI, height and calcium intake; Model 5 - adjusted for sex, energy, housing tenure, maternal education, birth weight, BMI, height and protein intake; Model 6 - adjusted for sex, energy, housing tenure, maternal education, birth weight, $\mathrm{BMI}$, height and animal protein intake.

animal protein intake strongly attenuated the association of IGF-I with cows' milk and dairy products. There was no strong evidence of confounding of the IGFBP-3 association with cows' milk and dairy products. Controlling for calcium increased the size of the regression coefficient of cows milk/dairy products on IGFBP-3. No significant associations were observed between cows' milk or dairy products intake and IGF-I/IGFBP-3 (data not shown).

As mentioned above, the only confounding factor to markedly attenuate the association of cows' milk/dairy products with IGF-I was protein. Cows' milk and dairy products were a major source of protein, with dairy products accounting on average for $40 \%$ of the children's animal protein intake, in comparison with $17 \%$ and $14 \%$ from poultry and processed meat, the next two highest sources. The regression coefficients ( $\beta$ (standard error)) for the energy-adjusted associations of total, dairy and non-dairy protein with IGF-I were respectively 0.00747 (0.00171), $\quad P<0.001 ; 0.00493 \quad(0.00217)$, $P=0.023$; and 0.00506 (0.00185), $P=0.006$. The regression coefficients for dairy and non-dairy protein were very similar, implying that protein per se rather than

Table 5 Change in height and leg length $Z$-score for each $100 \mathrm{~g}$ increase in cows' milk/dairy product consumption among boys $(n=287)$

\begin{tabular}{|c|c|c|c|c|}
\hline \multirow[b]{2}{*}{ Outcome variable } & \multicolumn{2}{|c|}{ Cows' milk } & \multicolumn{2}{|c|}{ Dairy products } \\
\hline & $B(95 \% \mathrm{Cl})$ & $P$ & $B(95 \% \mathrm{Cl})$ & $P$ \\
\hline \multicolumn{5}{|l|}{ Height } \\
\hline Model 1 & $0.023(-0.038,0.084)$ & 0.46 & $0.038(-0.020,0.096)$ & 0.20 \\
\hline Model 2 & $0.029(-0.024,0.083)$ & 0.28 & $0.035(-0.016,0.085)$ & 0.18 \\
\hline Model 3 & $0.004(-0.047,0.055)$ & 0.87 & $0.011(-0.037,0.059)$ & 0.65 \\
\hline Model 4 & $-0.022(-0.113,0.070)$ & 0.64 & $0.000(-0.102,0.103)$ & 1.00 \\
\hline Model 5 & $0.015(-0.042,0.072)$ & 0.60 & $0.023(-0.031,0.076)$ & 0.41 \\
\hline Model 6 & $0.012(-0.047,0.071)$ & 0.68 & $0.022(-0.035,0.078)$ & 0.45 \\
\hline \multicolumn{5}{|l|}{ Leg length } \\
\hline Model 1 & $0.047(-0.012,0.106)$ & 0.12 & $0.058(0.002,0.114)$ & 0.041 \\
\hline Model 2 & $0.050(-0.004,0.105)$ & 0.069 & $0.054(0.003,0.105)$ & 0.038 \\
\hline Model 3 & $0.027(-0.025,0.079)$ & 0.31 & $0.032(-0.017,0.081)$ & 0.20 \\
\hline Model 4 & $-0.022(-0.116,0.071)$ & 0.64 & $-0.008(-0.113,0.096)$ & 0.88 \\
\hline Model 5 & $0.043(-0.015,0.101)$ & 0.15 & $0.048(-0.006,0.103)$ & 0.083 \\
\hline Model 6 & $0.041(-0.019,0.101)$ & 0.18 & $0.049(-0.008,0.106)$ & 0.094 \\
\hline
\end{tabular}

$\mathrm{Cl}$ - confidence interval.

Model 1 - adjusted for energy intake; Model 2 - adjusted for energy intake, housing tenure, maternal education, birth weight and body mass index (BMI); Model 3 - adjusted for energy intake, housing tenure, maternal education, birth weight, BMI and insulin-like growth factor-I (IGF-I); Model 4 - adjusted for energy intake, housing tenure, maternal education, birth weight, BMI, IGF-I and calcium intake; Model 5 - adjusted for energy intake, housing tenure, maternal education, birth weight, BMI, IGF-I and protein intake; Model 6 - adjusted for energy intake, housing tenure, maternal education, birth weight, BMI, IGF-I and animal protein intake. 
dairy protein was the important factor. Thus these results are consistent with the cows' milk-IGF-I associations being mediated by protein.

Table 5 shows the multivariable associations of cows' milk and dairy products with anthropometry in boys. This analysis was restricted to boys as there was no evidence of any association of anthropometry with cows' milk/dairy products in females (see above). Leg length was the anthropometric variable with the strongest relationship with dairy products. Of the confounding factors investigated, only adjustment for IGF-I and calcium strongly attenuated the association between dairy products and leg length, indicating that these factors may mediate the association. A similar pattern was obtained in the models with height as the outcome, but the regression coefficients were smaller in each case. There was no evidence of a positive relationship between dairy products and sitting height (data not shown).

\section{Effect of excluding underreporters}

The analyses were repeated excluding possible underreporters ( 76 children excluded). The results were similar, but the associations between dairy products and IGFBP-3 and between dairy products and leg length in boys were slightly attenuated (data not shown).

\section{Discussion}

Among this group of 7- and 8-year-old children we found a number of associations between milk and dairy products consumption and IGF-I and its main binding protein IGFBP-3. Higher intakes of cows' milk and dairy products were significantly positively associated with concentrations of IGF-I and IGFBP-3 in all children and in boys, even after adjusting for a number of possible confounders. However, there were no associations between cows' milk or dairy products and the molar ratio IGF-I/IGFBP-3, a possible marker of IGF-I bioavailability. There were also no associations between IGF levels and cows' milk or dairy products in girls.

The associations between cows' milk/dairy products and IGF-I and IGFBP-3 were considerably more attenuated on adjustment for total or animal protein than for calcium. Furthermore, protein and animal protein from both all sources and non-dairy sources were positively associated with IGF-I in boys, and the strength of the associations with dairy and non-dairy protein were similar. This suggests that the apparent relationship between milk and IGF-I could reflect an underlying association with protein rather than with milk per se. In this group of children dairy products comprised the largest source of animal protein in their diet (see Appendix).

Dairy product intake was positively associated with leg length in boys. This association was considerably attenuated by adjustment for IGF-I, suggesting it may be one of the biological mediators of this association, although studies in adults on the association between IGF-I and height/leg length have had mixed results ${ }^{53,54}$. We speculated that the absence of associations between diet and anthropometry in girls might be related to the early onset of adrenarche or puberty in some of the older girls. Therefore the analysis was repeated in girls aged less than 8 years at the time of IGF measurement (approximately $40 \%$ of the original sample). In this subgroup we found, contrary to expectations, an inverse association between cows' milk and leg length (in Model 3, $\beta=-0.109(-0.196,-0.022)$ standard deviation score in leg length per $100 \mathrm{~g}$ increase in cows' milk intake). However, these were post hoc analyses and so should be interpreted with caution. In addition, there was no evidence of a statistical interaction between cows' milk/ dairy products and age with respect to their effect on IGF-I (among girls the $P$-values for the interaction terms age $\times$ cows' milk and age $\times$ dairy products were 0.19 and 0.14 , respectively).

\section{Strengths and limitations of the current study}

As far as we are aware, this is the first study to relate childhood diet to both leg length and IGF-I. Previous studies of diet-IGF associations have generally used foodfrequency questionnaires. We assessed diet using a 3-day unweighed food record. Unweighed food records have been shown to compare well with the results of weighed intakes, generally considered the gold standard of dietary assessment $^{55}$. One problem with food-frequency questionnaires is their limited ability to estimate energy intake, which has been shown to be positively associated with IGF-I levels ${ }^{56}$. As a result, despite attempts to control for energy intake, residual confounding by this factor may remain. The current study had good information on a range of sociodemographic confounders - most previous studies have made no attempt to control for any measure of social status. Controlling for these confounders had very little effect on the observed associations, suggesting it is unlikely that socially patterned confounding accounts for the relationships we have observed. However, a limitation of the analysis is its cross-sectional nature, which means it cannot determine the causality of any relationships between IGF-I levels and diet. In addition our sample was slightly biased in terms of socio-economic status, and in favour of taller girls, which may have removed some of the variation in diet and IGF levels and made it harder to detect significant relationships.

\section{Findings of other studies}

Most previous studies of the relationship between cows' milk and IGFs have been conducted in middle-aged and elderly men. Two large studies in the USA ${ }^{10,23}$ and one in the $\mathrm{UK}^{24}$ have found positive associations between milk/ dairy intake and IGF-I levels that persisted on adjustment for potential confounders. Relationships with protein intakes in these studies were less consistent. Two small 
studies of elderly men in Greece $\left(n=153^{27}\right.$ and $112^{28}$ ) found no association between cows' milk/dairy products and IGF-I, but may have lacked the statistical power to detect associations of the size seen in the other studies. There have been two studies in women, one in the USA ${ }^{25}$ and one in the $\mathrm{UK}^{26}$. Only the US study found a positive association with cows' milk/dairy products, but both studies found evidence of positive associations between protein intake and IGF-I.

We are aware of only one other study that has investigated the relationship between milk intake and IGF-I and linear growth in children. Among 90 Danish 2year-olds, intakes of milk and animal protein were positively associated with serum IGF-I and height in an analysis adjusting for body size, while intakes of vegetable protein and meat were not ${ }^{33}$.

\section{Conclusions}

We have found a positive association between cows' milk and dairy products and IGF levels in 7-8-year-old children that appears to be at least partly mediated by levels of protein intake. These results are in line with the majority of adult studies. Dairy product intake in boys was also positively associated with leg length, providing a possible mechanistic link with IGF-I mediating the effects of nutrition on long bone growth and the risk of cancer in adulthood. Conversely, cows' milk intake in the younger girls was inversely associated with leg length. It is unclear from these results how a recommendation to reduce intake of dairy products would affect IGF-I levels and prepubertal growth. Furthermore, there are a number of possible detrimental effects of reducing IGF-I levels. Lower IGF-I levels in adults have been linked to heart disease $^{57}$, diabetes ${ }^{58}$ and unfavourable changes in body composition in later life. In addition, higher IGF-I levels are associated with increased bone mineral density. Milk supplementation studies have found favourable effects on bone remodelling in adults ${ }^{29}$ and on bone mineral content in children $^{30}$, in addition to the effects on IGF-I. Any dietary recommendations should await a more complete understanding of the complex effects of IGF-I on longterm health and more conclusive evidence on the relationship between diet and IGF-I.

\section{Acknowledgements}

We are extremely grateful to the mothers who took part in this study and to the midwives for their co-operation and help in recruiting the mothers during pregnancy. We would like to acknowledge the dedicated work of the ALSPAC Study Team; this includes interviewers, computer technicians, clerical workers, research scientists, volunteers and managers. ALSPAC is part of the World Health Organization-initiated European Longitudinal Study of Pregnancy and Childhood. The ALSPAC study could not have taken place without the financial support of the University of Bristol, the Medical Research Council, the Wellcome Trust, the Department of the Environment, the Ministry of Agriculture, Fisheries and Food, various medical charities and commercial companies. This part of the study was funded by the World Cancer Research Fund.

\section{References}

1 Gunnell D, Okasha M, Davey Smith G, Oliver S, Sandhu J, Holly J. Height, leg length, and cancer risk: a systematic review. Epidemiologic Reviews 2001; 23: 313-42.

2 Gerver W, Bruin R. Relationship between height, sitting height and subischial leg length in Dutch children: presentation of normal values. Acta Paediatrica 1995; 84 $532-5$.

3 Gunnell D, Davey Smith G, Holly J, Frankel S. Leg length and risk of cancer in the Boyd Orr cohort. British Medical Journal 1998; 317: 1350-1.

4 Gunnell D. Commentary: Can adult anthropometry be used as a 'biomarker' for prenatal and childhood exposures? International Journal of Epidemiology 2002; 31: 390-4.

5 Butler A, Le Roith D. Control of growth by the somatropic axis: growth hormone and the insulin-like growth factors have related and independent roles. Annual Review of Physiology 2001; 63: 141-64.

6 Juul A, Dalgaard P, Blum W. Serum levels of insulin-like growth factor (IGF)-binding protein-3 (IGFBP-3) in healthy infants, children and adolescents: the relation to IGF-I, IGFII, IGFBP-1, IGFBP-2, age, sex, body mass index and pubertal maturation. Journal of Clinical Endocrinology and Metabolism 1995; 80: 2534-42.

7 Chan J, Stampfer M, Giovannucci E, Gann PH, Ma J, Wilkinson P, et al. Plasma insulin-like growth factor-I and prostate cancer risk: a prospective study. Science 1998; 279: 563-6.

8 Wolk A, Mantzoros CS, Andersson SO, Bergstrom R, Signorello LB, Lagiou $\mathrm{P}$, et al. Insulin-like growth factor I and prostate cancer risk: a population-based case-control study. Journal of the National Cancer Institute 1998; 90: $911-5$.

9 Hankinson S, Willett W, Colditz G, Hunter D, Michaud D, Deroo B, et al. Circulating concentrations of insulin-like growth factor I and risk of breast cancer. Lancet 1998; 351: 1393-6.

10 Ma J, Giovannucci E, Pollak M, Chan J, Gaziano J, Willett W, et al. Milk intake, circulating levels of insulin-like growth factor-I, and risk of colorectal cancer in men. Journal of the National Cancer Institute 2001; 93: 1330-6.

$11 \mathrm{Yu} \mathrm{H}$, Rohan T. Role of the insulin-like growth factor family in cancer development and progression. Journal of the National Cancer Institute 2000; 92: 1472-89.

12 Giovannucci E. Insulin, insulin-like growth factors and colon cancer: a review of the evidence. Journal of Nutrition 2001; 131(Suppl.): S3109-20.

13 Renehan A, Zwahler M, Minder C, O'Dwyer S, Shalet S, Egger M. Insulin-like growth factor (IGF)-I, IGF binding protein 3 and cancer risk: systematic review and meta-regression analysis. Lancet 2004; 363: 1346-53.

14 Kristal AR, Cohen J, Qu P, Stanford JL. Associations of energy, fat, calcium and vitamin D with prostate cancer risk. Cancer Epidemiology, Biomarkers \& Prevention 2002; 11: $719-25$.

15 Giovannucci E, Rimm E, Stampfer M, Colditz G, Ascherio A, Willett W. Intake of fat, meat and fiber in relation to risk of colon cancer in men. Cancer Research 1994; 54: 2390-7.

16 Kolonel L. Fat, meat and prostate cancer. Epidemiologic Reviews 2001; 23: 72-81. 
17 Chan J, Giovannucci E. Dairy products, calcium, vitamin D and risk of prostate cancer. Epidemiologic Reviews 2001; 23: $87-92$.

18 World Cancer Research Fund (WCRF)/American Institute for Cancer Research (AICR). Food, Nutrition and the Prevention of Cancer: A Global Perspective. Washington, DC: WCRF/AICR, 1997.

19 Trichopoulou A, Katsouyanni K, Stuver S, Tzala L, Gnardellis C, Rimm E, et al. Consumption of olive oil and specific food groups in relation to breast cancer risk in Greece. Journal of the National Cancer Institute 1995; 87: 110-6.

20 Chan J, Giovannucci E. Vegetables, fruits, associated micronutrients and risk of prostate cancer. Epidemiologic Reviews 2001; 23: 82-6.

21 Freudenheim JL, Marshall J, Vena J, Laughlin J, Brasure J, Swanson M, et al. Premenopausal breast cancer risk and intake of vegetables, fruits and related nutrients. Journal of the National Cancer Institute 1996; 88: 340-8.

22 Key T, Allen N, Spencer E, Travis R. The effect of diet on risk of cancer. Lancet 2002; 360: 861-8.

23 Giovannucci E, Pollak M, Liu Y, Platz E, Majeed N, Rimm E, et al. Nutritional predictors of insulin-like growth factor I and their relationships to cancer in men. Cancer Epidemiology, Biomarkers \& Prevention 2003; 12: 84-9.

24 Gunnell D, Oliver S, Peters T, Donovan J, Persad R, Maynard $\mathrm{M}$, et al. Are diet-prostate cancer associations mediated by the IGF axis? A cross-sectional analysis of diet, IGF-I and IGFBP-3 in middle-aged men. British Journal of Cancer 2003; 88: 1682-6.

25 Holmes M, Pollak M, Willett W, Hankinson S. Dietary correlates of plasma insulin-like growth factor I and insulin-like growth factor binding protein 3 concentrations. Cancer Epidemiology, Biomarkers \& Prevention 2002; 11: $852-61$.

26 Allen N, Appleby P, Davey G, Kaaks R, Rinaldi S, Key T. The associations of diet with serum insulin-like growth factor I and its main binding proteins in 292 women meat-eaters, vegetarians and vegans. Cancer Epidemiology, Biomarkers $\&$ Prevention 2002; 11: 1441-8.

27 Signorello L, Kuper H, Lagiou P, Mucci L, Trichopoulos D, Adami HO. Lifestyle factors and insulin-like growth factor I levels among elderly men. European Journal of Cancer Prevention 2000; 9: 173-8.

28 Mucci L, Tamimi R, Lagiou P, Trichopoulou A, Benetou V, Spanos E, et al. Are dietary influences on the risk of prostate cancer mediated through the insulin-like growth factor system? BJU International 2001; 87: 814-20.

29 Heaney RP, McCarron D, Dawson-Huges B, Oparil S, Berga $\mathrm{S}$, Stern J, et al. Dietary changes favorably affect bone remodeling in older adults. Journal of the American Dietetic Association 1999; 99: 1228-33.

30 Cadogan J, Eastell R, Jones N, Barker M. Milk intake and bone mineral acquisition in adolescent girls: randomised, controlled intervention trial. British Medical Journal 1997; 315: $1255-60$.

31 Hoppe C, Mølgaard C, Juul A, Michaelsen K. High intakes of skimmed milk, but not meat, increase serum IGF-I and IGFBP-3 in eight-year-old boys. European Journal of Clinical Nutrition 2004; 58: 1211-6.

32 Frankel S, Gunnell DJ, Peters TJ, Maynard M, Davey Smith G. Childhood energy intake and adult mortality from cancer: the Boyd Orr Cohort Study. British Medical Journal 1998; 316: 499-504.

33 Hoppe C, Udam T, Lauritzen L, Mølgaard C, Juul A, Michaelsen K. Animal protein intake, serum insulin-like growth factor I, and growth in healthy 2.5-y-old Danish children. American Journal of Clinical Nutrition 2004; 80: $447-52$.

34 Golding J, Pembrey M, Jones R, ALSPAC Study Team. ALSPAC - The Avon Longitudinal Study of Parents and
Children. I. Study methodology. Paediatric and Perinatal Epidemiology 2001; 15: 74-87.

35 ALSPAC website, http://www.alspac.bris.ac.uk

36 Price GM, Paul AA, Key FB, Harter AC, Cole TJ, Day KC, et al. Measurement of diet in a large national survey: comparison of computerised and manual coding of records in household measures. Journal of Human Nutrition and Dietetics 1995; 8: $417-28$.

37 Holland B, Welch AA, Unwin ID, Buss DH, Paul AA, Southgate DAT. McCance \& Widdowson's The Composition of Foods, 5th ed. Cambridge: The Royal Society of Chemistry, 1991.

38 Holland B, Unwin ID, Buss DH. Cereals and Cereal Products. Third Supplement to McCance \& Widdowson's The Composition of Foods, 4th ed. Cambridge: The Royal Society of Chemistry, 1988.

39 Holland B, Unwin ID, Buss DH. Milk Products and Eggs. Fourth Supplement to McCance \& Widdowson's The Composition of Foods, 4th ed. Cambridge: The Royal Society of Chemistry, 1989.

40 Holland B, Unwin ID, Buss DH. Vegetables, Herbs and Spices. Fifth Supplement to McCance \& Widdowson's The Composition of Foods, 4 th ed. Cambridge: The Royal Society of Chemistry, 1991.

41 Holland B, Unwin ID, Buss DH. Fruit and Nuts. First Supplement to McCance \& Widdowson's The Composition of Foods, 5th ed. Cambridge: The Royal Society of Chemistry, 1992.

42 Holland B, Welch AA, Buss DH. Vegetable Dishes. Second Supplement to McCance \& Widdowson's The Composition of Foods, 5th ed. Cambridge: The Royal Society of Chemistry, 1992.

43 Holland B, Brown J, Buss DH. Fish and Fish Products. Third Supplement to McCance \& Widdowson's The Composition of Foods, 5th ed. Cambridge: The Royal Society of Chemistry, 1993.

44 Chan W, Brown J, Buss DH. Miscellaneous Foods. Fourth Supplement to McCance \& Widdowson's The Composition of Foods, 5th ed. Cambridge: The Royal Society of Chemistry, 1994.

45 Chan W, Brown J, Lee SM, Buss DH. Meat, Poultry and Game. Fifth Supplement to McCance \& Widdowson's The Composition of Foods, 5 th ed. Cambridge: The Royal Society of Chemistry, 1995.

46 Chan W, Brown J, Church SM, Buss DH. Meat Products and Dishes. Sixth Supplement to McCance \& Widdowson's The Composition of Foods, 5 th ed. Cambridge: The Royal Society of Chemistry, 1996.

47 Cameron N. The methods of auxological anthropometry. In: Falkner F, Tanner JM, eds. Human Growth: A Comprehensive Treatise 3. New York/London: Plenum Press, 1986; 3-46.

48 Lemmey A, Maddison P, Breslin A, Cassar P, Hasso N, McCann R, et al. Association between insulin-like growth factor status and physical activity levels in rheumatoid arthritis. Journal of Rheumatology 2001; 28: $29-34$.

49 Willett W, Stampfer M. Total energy intake: implications for epidemiologic analyses. American Journal of Epidemiology 1986; 124: 17-27.

50 Garnett S, Cowell C, Bradford D, Lee J, Tao C, Petrauskas V, et al. Effects of gender, body composition and birth size on IGF-I in 7-and 8-year-old children. Hormone Research 1999; 52: $221-9$.

51 Torun B, Davies P, Livingstone MBE, Paolisso M, Sackett R, Spurr GB. Energy requirements and dietary energy recommendations for children and adolescents 1 to 18 years old. European Journal of Clinical Nutrition 1996; 50(Suppl.1): S37-81.

52 Freeman JV, Cole TJ, Chinn S, Jones PRM, White EM, Preece 
MA. Cross sectional stature and weight reference curves for the UK, 1990. Archives of Disease in Childhood 1995; 73: $17-24$.

53 Gunnell D, Oliver SE, Donovan JL, Peters TJ, Gillatt D, Persad R, et al. Do height-related variations in insulin-like growth factors underlie the associations of stature with adult chronic disease? Journal of Clinical Endocrinology and Metabolism 2004; 89: 213-8.

54 DeLellis K, Rinaldi S, Kaaks R, Kolonel L, Henderson B, Le Marchand L. Dietary and lifestyle correlates of plasma insulin-like growth factor-I (IGF-I) and IGF binding protein 3 (IGFBP-3): The Multiethnic Cohort. Cancer Epidemiology, Biomarkers \& Prevention 2004; 13: 1444-51.

55 Bingham SA, Gill C, Welch A, Day K, Cassidy A, Khaw KT, et al. Comparison of dietary assessment methods in nutritional epidemiology: weighed records v. $24 \mathrm{~h}$ recalls, food-frequency questionnaires and estimated-diet records. British Journal of Nutrition 1994; 72: 619-43.

56 Thissen J, Ketelslegers J, Underwood L. Nutritional regulation of the insulin-like growth factors. Endocrine Reviews 1994; 15: 80-101.

57 Juul A, Scheike F, Davidsen M, Gyllenborg J, Jorgensen T. Low serum insulin-like growth factor I is associated with increased risk of ischaemic heart disease. Circulation 2002; 106: 939-44.

58 Sandhu M, Heald A, Gibson J, Cruickshank J, Dunger DB, Wareham N. Circulating concentrations of insulin-like growth factor-I and development of glucose intolerance: a prospective observational study. Lancet 2002; 359 $1740-5$.

\section{Appendix - Correlation matrices of hormonal, anthropometric and dietary variables}

\begin{tabular}{|c|c|c|c|c|c|c|c|c|c|}
\hline & Height & Leg length & Sitting height & Cows' milk & Dairy products & Calcium & Protein & Animal protein & Energy \\
\hline \multicolumn{10}{|l|}{ Boys } \\
\hline IGF-I & $0.388^{\star \star \star}$ & $0.358^{\star \star \star}$ & $0.332^{\star \star \star}$ & $0.144^{*}$ & $0.175^{\star \star}$ & $0.141^{*}$ & $0.235^{\star \star \star}$ & $0.191^{\star *}$ & $0.114^{*}$ \\
\hline IGFBP-3 & $0.268^{\star \star \star}$ & $0.271^{\star \star \star}$ & $0.201^{\star * *}$ & $0.143^{\star}$ & $0.166^{\star *}$ & 0.111 & $0.143^{*}$ & 0.087 & $0.153^{\star *}$ \\
\hline Molar ratio & $0.186^{\star \star \star}$ & $0.151^{\star \star}$ & $0.184^{\star \star}$ & 0.022 & 0.041 & 0.057 & $0.130^{*}$ & $0.129^{\star}$ & -0.004 \\
\hline Height & & $0.909^{\star \star \star}$ & $0.872^{\star \star \star}$ & $0.171^{\star \star}$ & $0.200^{* \star *}$ & $0.105^{\star}$ & 0.096 & 0.064 & $0.253^{\star \star *}$ \\
\hline Leg length & & & $0.589^{\star \star *}$ & $0.177^{\star \star \star}$ & $0.205^{\star \star \star}$ & $0.144^{\star \star}$ & 0.082 & 0.065 & $0.205^{\star * *}$ \\
\hline Sitting height & & & & $0.111^{\star}$ & $0.134^{\star *}$ & 0.038 & 0.089 & 0.048 & $0.247^{\star \star \star}$ \\
\hline Cows' milk & & & & & $0.961^{* * *}$ & $0.771^{\star * *}$ & $0.369^{\star \star *}$ & $0.410^{\star * *}$ & $0.367^{\star * *}$ \\
\hline Dairy products & & & & & & $0.799^{* \star *}$ & $0.370^{\star \star *}$ & $0.435^{\star \star \star}$ & $0.429^{* \star *}$ \\
\hline Calcium & & & & & & & $0.482^{\star \star \star}$ & $0.483^{\star \star \star}$ & NA \\
\hline Protein & & & & & & & & $0.875^{\star \star \star}$ & NA \\
\hline \multicolumn{10}{|l|}{ Girls } \\
\hline IGF-I & $0.189^{* *}$ & 0.112 & $0.231^{\star \star \star}$ & 0.007 & -0.020 & 0.055 & 0.115 & 0.090 & -0.021 \\
\hline IGFBP-3 & $0.202^{* * *}$ & $0.154^{* *}$ & $0.207^{\star \star \star}$ & 0.048 & 0.056 & -0.032 & -0.029 & -0.049 & 0.101 \\
\hline Molar ratio & 0.014 & -0.022 & 0.050 & 0.016 & -0.021 & 0.085 & $0.142^{*}$ & $0.135^{\star}$ & -0.112 \\
\hline Height & & $0.912^{\star \star \star}$ & $0.868^{\star \star \star}$ & -0.042 & 0.005 & -0.020 & -0.049 & -0.085 & $0.159^{\star \star}$ \\
\hline Leg length & & & $0.588^{\star \star *}$ & -0.069 & -0.028 & -0.045 & -0.041 & -0.077 & $0.135^{\star}$ \\
\hline Sitting height & & & & -0.009 & 0.036 & 0.000 & -0.046 & -0.073 & $0.147^{\star \star}$ \\
\hline Cows' milk & & & & & $0.945^{\star \star \star}$ & $0.721^{\star \star \star}$ & $0.412^{\star \star \star}$ & $0.462^{\star \star \star}$ & $0.170^{\star \star}$ \\
\hline Dairy products & & & & & & $0.756^{\star \star \star}$ & $0.415^{\star \star \star}$ & $0.485^{\star \star \star}$ & $0.250^{\star \star *}$ \\
\hline Calcium & & & & & & & $0.491^{\star \star *}$ & $0.505^{\star \star \star}$ & NA \\
\hline Protein & & & & & & & & $0.890^{* * *}$ & NA \\
\hline
\end{tabular}

IGF-I - insulin-like growth factor-I; IGFBP-3 - insulin-like growth factor-binding protein-3; NA - not applicable.

${ }^{*}, P<0.05 ;{ }^{* *}, P<0.01 ;{ }^{* \star}, P<0.001$. 